\title{
HACIA UNA TEORÍA DE LA VARIAGIÓN METAFÓRICA EN EL TEXTO LITERARIO ANÁLISIS DE DOS POEMAS DE ENRIQUE GONZÁLEZ MARTÍNEZ
}

Metáfora y poesía parecen asociarse natural y legítimamente. Según un lugar común que se remonta en sus orígenes al pensamiento de Roman Jakobson, la estructura poética se funda en la metáfora, en tanto que las formas literarias cuyo medio de expresión es la prosa serían esencialmente metonímicas. Incluso en una obra de tan amplio alcance como La métaphore vive de Paul Ricoeur, se dedica una atención preponderante a las relaciones entre metáfora y "poésie" o "discours poétique" (aun cuando hay que apuntar que estos términos parecen tener, para Ricoeur, una acepción más amplia de la que normalmente se les confiere).

El atribuir validez teórica a este vínculo aparentemente tan íntimo entre metáfora y poesía me parece no sólo una simplificación de los hechos, sino un error de principio. El sentido común nos indica que la metáfora opera de manera eficaz y no trivial en contextos no poéticos y no literarios, de tal suerte que situar su funcionamiento en el texto literario dentro del marco de una teoría general del texto verbal es una posibilidad razonable e interesante. Es también fácil de comprobar que la metáfora, concebida en sus términos más generales, remite a principios generales de la articulación del sentido que no inciden en la conformación específica del lenguaje y que, por consiguiente, rebasan los límites de una teoría formal del lenguaje. Con respecto a este punto, remito a la inteligente apreciación de Sadock ${ }^{1}$.

La definición de lo que es la metáfora no incumbe, pues, ni

${ }^{1}$ J. M. SADOCK, "Figurative speech and linguistics", en A. Orthony (ed.), Metaphor and Thought, Cambridge University Press, Cambridge, 1979. Cabe apuntar, sin embargo, ciertas reservas con respecto a la definición que hace Sadock de la metáfora como un tipo particular de acto de habla. Tal idea no encuentra ningún apoyo en las publicaciones de Searle sobre actos de habla. 
al lingüista ni al crítico literario, pero no por eso les dejan de interesar los efectos de la expresión metafórica en el texto. El propósito de este ensayo es trazar un camino hacia una teoría del funcionamiento de la metáfora en el texto literario, considerándolo en relación con una teoría general del texto. Se contrastarán, en este intento, dos enfoques teóricos, uno de los cuales se puede identificar con una perspectiva contextual y pragmática sobre el lenguaje, y el otro con la poética estructuralista. El primero es de John Searle, enunciado explícitamente por primera vez en una conferencia de 1977, y concebido como una extensión o aplicación de su conocida teoría de los actos de habla (speech acts) ${ }^{2}$; el segundo es el de Samuel Levin, quien aporta concepciones típicas de la poética estructuralista al análisis textual de la metáfora en poemas líricos3. Se intentará poner de relieve las

${ }^{2}$ Su trabajo "Metaphor" fue presentado inicialmente en el congreso sobre la metáfora que tuvo lugar en la Universidad de Illinois (UrbanaChampaign) en 1977, y fue publicado posteriormente tanto en las actas del congreso editadas por A. ORTHONY (ibid.) como en su propio libro, Expression and Meaning. Studies in the Theory of Speech Acts, Cambridge University Press, Cambridge, 1979.

${ }^{3}$ S. R. LEV1N, "Concerning what kind of speech act a poem is", en T. A. Van Dijk (ed.), Pragmatics of Language and Literature, North-Holland, Amsterdam, 1976, y "Standard Approaches to Metaphor and a Proposal for Literary Metaphor', en Orthony, op. cit., Por razones de comodidad y de espacio, nos limitamos aquí a exponer las ideas de Levin (y no las de otros especialistas de la misma tendencia), ya que las enuncia en una forma particularmente clara y sencilla, y las lleva directamente al análisis textual concreto.

No hay que olvidar, sin embargo, que sus ideas se sitúan en el marco de una tradición de teoría poética y estética. La idea de formular una teoría específicamente literaria de la metáfora se encuentra también en BEARDSLEY, por ejemplo (Aesthetics, Harcourt, Brace and World, New York, 1958, p. 134), quien pretende ver un isomorfismo entre la metáfora y la estructura de la obra literaria en su conjunto. Según este enfoque, la metáfora, en calidad de unidad microcósmica o poema en miniatura, puede servir de "test case" para el análisis de la obra entera. De ahí se desprende que Beardsley atribuye a la metáfora características específicamente literarias y considera que se puede analizar en sí como objeto estético.

Con respecto a la pretendida originalidad de la metáfora literaria, Ricoeur la asocia con las funciones estéticas de la metáfora, por oposición a las que él caracteriza como funciones lingüísticas. No es difícil detectar en el punto de vista de Ricoeur la tradicional concepción lexicalista de la metáfora que Searle critica, como más adelante se verá. "La contraparte de este tratamiento lógico-lingüístico de la denominación metafórica - dice Ricoeur- es la disyunción que de él se desprende entre metáfora lingüistica y metáfora estética, siendo ésta la expresión estilística de la metáfora. Sólo algunas de las funciones de la metáfora estética prolongan las de la metáfora lingüística (crear términos nuevos, compensar la indigencia del vocabulario). Lo esencial de la 
diferentes conceptualizaciones del texto implícitas en los dos enfoques, al igual que ciertas ideas reduccionistas que constituyen un peligro para quienes quieren asociar la metáfora con la "poeticidad" del lenguaje.

Aunque no es mi intención ocuparme de las cuestiones filosóficas que suscita la metáfora, comentaré ciertos puntos de contacto que el enfoque de Searle puede tener con los de otros filósofos modernos especialistas en este campo, en particular Paul Ricoeur y Max Black ${ }^{4}$. Consideraré, además, las implicaciones que podría tener el enfoque searliano para una conceptualización de la variabilidad del texto literario como la que propone Roger Fowler

Por último, se ilustrarán las observaciones teóricas por medio de un análisis de dos poemas de Enrique González Martínez, seleccionados como ejemplos dignos de la tradición poética moderna en Latinoamérica.

El interés de las ideas de Searle sobre la metáfora se debe en gran parte al marco teórico general en que se sitúan: la teoría de los actos de habla ${ }^{6}$, que permite por primera vez establecer una relación explícita entre una teoría formal del lenguaje y una teoría del discurso, relación fundada en la convicción de que, como dice Teun van Dijk, "la reconstrucción teórica de enunciados en los niveles de la forma y del sentido debe complementarse con un tercer nivel, es decir, el nivel de la acción'?. Searle logra sistematizar la descripción de la dimensión pragmática del lenguaje mediante la distinción entre "acto enunciativo" ("utterance act": el acto de enunciar un mensaje lingüístico en un contexto comunicativo determinado), "acto locutivo"' ("locutionary act': el acto proposicional o referencial que el emisor realiza en el mensaje), "acto ilocutivo" ("illocutionary act": el acto de afirmar, ordenar, prometer, etc., realizado por el emisor por medio de un mensaje

metáfora estética está en otra parte. Su mira es la de crear la ilusión, sobre todo mediante la presentación del mundo bajo un aspecto nuevo", La métaphore vive, Éds. du Seuil, Paris, 1975, pp. 138-139. (Las traducciones de este artículo son mías.)

${ }^{4}$ Sus obras claves son la ya citada de Ricoeur (ibid.), y de Black, Models and Metaphors, Cornell University Press, Ithaca, NY, 1962.

${ }^{5}$ En Literature as Social Discourse. The practice of Linguistic Criticism, Batsford Academic and Educational, London, 1981.

${ }^{6}$ Speech Acts. An Essay in the Philosophy of Language, Cambridge University Press, Cambridge, 1969.

${ }^{7}$ T. A. VAN DijK, Text and Context. Explorations in the Semantics and Pragmatics of Discourse, Longman, London, 1977, p. 2. 
verbal) y, en forma marginal, "acto perlocutivo"' ("perlocutionary act'': el efecto que causa la enunciación, como acto, en el interlocutor $)^{8}$.

La propuesta de Searle para la descripción de la metáfora comprende dos aspectos fundamentales: el primero, y el más interesante, es la atribución del sentido metafórico al acto enunciativo en vez del acto locutivo o proposicional: "Para distinguir de manera concisa entre, por una parte, lo que un sujeto hablante quiere significar mediante la enunciación de palabras, oraciones y expresiones y, por otra, lo que significan en sí las palabras, oraciones y expresiones, llamaré al primero el sentido enunciativo del hablante (speaker's ustterance meaning), y al segundo el sentido léxico $u$ oracional (word, or sentence meaning). El sentido metafórico siempre es sentido enunciativo del hablante"'9. La misma noción, que

${ }^{9}$ Searle, Expression and Meaning..., p. 77. Los argumentos que L. J. CoHEN presenta contra este punto de vísta en "The semantic of metaphor" (Orthony, ed., op. cit., pp. 64-77) nos parecen, en términos generales, espurios. Cohen aduce, como incoveniente para la teoría searliana, el hecho de que el sentido metafórico se conserve bajo el efecto de una transformación, mientras que la fuerza ilocutoria de un mandato, por ejemplo, sí se pierde. Cohen confunde aquí el sentido enunciativo con el acto enunciativo. Searle describe la metáfora como un sentido que se comunica en el acto enunciativo, no como un acto en sí. De esta manera el sentido metafórico se conserva exactamente como se conserva el sentido, pero no la fuerza ilocutiva, del mandato en: "Tomás dijo que se cerrara la puerta". Obviamente esta oración no puede ser enunciada como mandato, pero no tenemos ninguna dificultad en inferir de ella que en una determinada situación en el pasado Tomás emitió tal acto de habla.

Otro ejemplo de Cohen, para mostrar que la interpretación de la metáfora se puede hacer en forma independiente de su contexto enunciativo: "Tom said that the boy next door is a ball of fire" (el ejemplo se cita en inglés ya que el sentido metafórico es intraducible). Podríamos quizá tratar de demostrar que la metáfora depende de su contexto de enunciación variando el ejemplo (las connotaciones de "Tom said that the girl next door is a ball of fire" podrían ser bien diferentes) o contrastando la metáfora con un posible sentido literal (si el muchacho sale corriendo de su casa incendiada con su ropa ardiendo, el ejemplo podría tener un sentido literal, aunque forzado). Más convincente, sin embargo, resulta otro ejemplo en el que la variación contextual de sentidos se aprecia en forma patente: "Tom said that Sam is a pig". El valor preciso de "pig" aquí dependerá de las intenciones de Tom, ya que el término permite una variedad de sentidos metafóricos convencionales: comer cantidades excesivas, tener modales o hábitos sucios, ser cruel y déspota o generalmente antipático, ser miembro de alguna organización o partidario de alguna corriente ideológica que se considera nefasta y represiva, etc.). En una situación determinada Tom podría enunciar la preposición sobre Sam con uno u otro de los sentidos mencionados, o con varios a la vez, y sólo podrá captar 
ya se podía inferir del ensayo de 1975 en el que Searle trata los actos de habla indirectos ${ }^{10}$, había servido de base a toda una corriente de estudios sobre la metáfora en el campo de la psicología cognoscitiva ${ }^{11}$. Es más: partiendo del principio, reconocido sobre todo por psicólogos y especialistas de la inteligencia artificial, de que "las palabras tienen significados variables que se ubican de acuerdo a límites fluctuantes y dependientes del contexto, más bien que a conjuntos fijos de componentes semánticos"'12, se ha llegado a poner en duda la posibilidad o la utilidad de reducir el llamado "sentido literal" de una oración a su contenido proposicional para el nivel de lo que el lingüista llama "actuación" ("performance"').

El segundo aspecto que contiene la propuesta de Searle es la postulación de una serie de principios lógicos que permiten al hablante pasar de una interpretación literal de un mensaje hacia una metafórica e indirecta en un contexto comunicativo determinado. Uno de estos principios, el de buscar un sentido figurado donde el sentido literal de una enunciación parece lógicamente defectuoso (situación que se presenta con frecuencia, sin ser condición necesaria, en los contextos metafóricos), se concreta en la estrategia siguiente: "donde el enunciado resulta defectuoso si se interpreta literalmente, busca un sentido enunciativo que difiera del sentido

el interlocutor este sentido o estos sentidos evaluando las intenciones comunicativas de Tom. Son estas intenciones y no la función "desambiguadora" del contexto (que permite distinguir, en cambio, entre sentidos figurados y literales) el elemento clave para la interpretación.

Otro argumento de Cohen consiste en señalar que la función "desambiguadora" del contexto opera tanto con sentidos literales como con los metafóricos, y que no hay, por consiguiente, bases suficientes para fundar una teoría de la metáfora en la teoría de los actos de habla. Pero contra esto se puede argumentar que, para captar la realidad pragmática de la enunciación, la teoría de los actos de habla no sólo es necesaria para el lenguaje metafórico, sino para el lenguaje en general (incluyendo toda expresión literal). La manera en que Searle enfoca la enunciación de sentidos metafóricos depende, de hecho, de su manera de enfocar la enunciación literal. El argumento de Cohen carece de toda lógica.

${ }^{10}$ J. R. Searle, "Indirect Speech Acts", en P. Cole y J. L. Morgan (eds.), Syntax and Semantics, t. 3: Speech Acts, Academic Press, New York, 1975.

${ }_{11}$ Véanse, por ejemplo, H. H. ClaRK, "Responding to Indirect Speech Acts", $\operatorname{Cog} P, 11$ (1979), 430-477; H. H. CLARK y P. LUCY, "Understanding What is Meant from What is Said: A Study in Conversationally Conveyed Requests", JVLVB, 14 (1975), 56-72; R. W. GibBs, "A Critical Examination of the Contribution of Literal Meaning to Understanding Nonliteral Discourse", T. 2 (1982), 9-27.

12 Véase el artículo de GıBBs citado en la nota anterior. 
oracional" 13 . Este principio ha sido muy criticado por psicólogos que han demostrado con datos experimentales que el hablante no recurre ni necesaria ni sistemáticamente, en su actuación verbal, al sentido literal de un enunciado como paso previo a una interpretación metafórica ${ }^{14}$. Irónicamente, Searle parece plantear, en este caso, una interacción entre el sentido literal y el figurado en el contexto de la enunciación, que no deja de recordar aspectos de las teorías "interaccionistas" de Black y otros que él mismo critica.

Si la propuesta de Searle, tal como está, parece no ajustarse al tipo de modelo de procesamiento verbal que requiere el psicólogo, es innovadora al replantear la conceptualización de la metáfora en términos de su realización activa en el proceso de la comunicación, en vez de recurrir a los criterios ontológicos, simbólicos y semánticos que habían prevalecido en las teorías tradicionales. El enfoque que presenta es precisamente uno que aspira a relacionar "competencia" lingüística con comportamiento verbal:

Ya que los conocimientos que permiten a la gente producir y comprender enunciados metafóricos van más allá de su conocimiento de los sentidos literales de las palabras y las oraciones, los principios que buscamos no se incluyen, o por lo menos no se incluyen enteramente, dentro de una teoría de la competencia semántica tal como ésta se concibe tradicionalmente. Desde el punto de vista del interlocutor, el problema enfocado por una teoría de la metáfora consiste en explicar cómo puede el interlocutor comprender el sentido enunciativo del hablante, dado que sólo oye una oración que contiene sentido léxico y oracional. Desde el punto de vista del hablante, el problema consiste en explicar cómo este puede querer decir algo diferente del sentido léxico y oracional de la oración que enuncia. A la luz de estas consideraciones, nuestra pregunta original, ¿Cómo funcionan las metáforas?, puede reformularse de la manera siguiente: ¿Cuáles son los principios que permiten a los hablantes enunciar, y a los interlocutores comprender, enunciados metafóricos? ${ }^{15}$

${ }^{13}$ Searlee, Expression and Meaning..., p. 105.

14 GiBBS, art. cit.

${ }^{15}$ Searle, Expression and Meaning..., p. 78. Vale la pena hacer hincapié en la última parte de esta cita. La meta de Searle es investigar cómo funciona la metáfora en el comportamiento verbal, no definir la esencia de la metáfora ni indagar por qué la gente emplea metáforas. Morgan ("Observations on the Pragmatics of Metaphor", Orthony, op. cit., p. 147) se plantea esta última pregunta, observando - acertadamente, en nuestra opinión- que "until we 
Es esta preocupación - no por la metáfora en sí, sino por su realización lingüística y (con)textual - la que motiva las críticas de Searle a las teorías tradicionales de la metáfora. Las divide, siguiendo el ejemplo de Beardsley y Black, en dos tipos fundamentales: las que postulan, desde tiempos de Aristóteles, una comparación o relación de semejanza entre dos (o más) entidades, y las de origen más reciente que postulan una interacción u oposición verbal entre dos contenidos semánticos.

Las teorías de comparación, dice Searle, confunden el sentido de los términos (lingüísticos) relacionados metafóricamente con las inferencias que permiten al emisor producir la metáfora, y al receptor comprenderla. Con ejemplos tales como "Sally is a block of ice" y "Richard is a gorilla" (pp. 87-91), demuestra que las expresiones metafóricas no son ipso facto aseveraciones de similitud, sino que cualquier relación de semejanza asociada con ellas forma parte del proceso de comprensión efectuado por el receptor o interlocutor: "las semejanzas funcionan como una estrategia de comprensión, no como un componente del sentido"' (p. 90). En concreto, los ejemplos citados son afirmaciones sobre Sally y Richard, respectivamente, y los rasgos convencionales (reales o imaginarios) que se atribuyen al hielo y a los gorilas no afectan en nada las condiciones de verdad de las proposiciones. Si se compara a Richard, por ejemplo, con un gorila por su carácter antipático y violento, huelga demostrar que los gorilas son en realidad animales mansos: tal evidencia no invalida la proposición. Ahora bien, podríamos argumentar que los atributos de los gorilas y del hielo en estos casos son conceptos establecidos por convención sociocultural que de alguna manera quedan desligados referencialmente de los conjuntos de individuos que normalmente se designan como gorilas y bloques de hielo. Pero el mismo carácter convencional de estos conceptos es lo que los une a sus contextos de enunciación. De todas formas, el sentido metafórico no se puede reducir a una comparación lógica y literal, y la relación entre sentido metafórico y sentido literal es demasiado compleja como para enfo-

get at the question of why metaphor is used, I doubt that we will ever understand what it is", y lamentando que Searle "apparently assumes that the fundamental questions of metaphor can be dealt with and understood without worrying about its purposes". No creemos que Searle haya afirmado en ninguna parte que quiera resolver los problemas "fundamentales" de la metáfora; más bien advertimos en sus escritos una conciencia nítida de los límites de su campo de investigación y si no se ocupa de los problemas "fundamentales" de la metáfora es porque trascienden la explicación de su funcionamiento en el comportamiento verbal. 
carse como simple efecto de sustitución.

Para Max Black, las teorías de comparación constituyen una versión especial de las teorías de sustitución, según las cuales la metáfora sirve de sustituto a una expresión literal. Reducir una metáfora a una analogía literal explícita es, según Black, una tarea inútil y mal concebida, ya que: "conforme nos vamos acercando a tales formas, las declaraciones metafóricas van perdiendo su eficacia y su razón de ser. Necesitamos las metáforas precisamente para aquellos casos en los que todavía no existe la posibilidad de una declaración científica exacta. Las declaraciones metafóricas no son sustitutos de comparaciones formales ni de cualquier otro género de declaración literal, sino que tienen sus logros y potencialidades propios y peculiares"' ${ }^{16}$. La distinción esbozada entre el discurso científico y un discurso que hiciera uso de la metáfora recibe la atención más amplia que merece en Ricoeur ${ }^{17}$.

Black propone enfocar en su propia teoría, no las entidades a las que se hace referencia por medio del lenguaje, sino las palabras mismas (es decir, para nosotros, el texto verbal). En este nivel operaría, según él, una interacción entre el término metafórico y al menos un término entendido literalmente:

"The chairman plowed through the discussion". Al llamar esta oración ejemplo de metáfora, insinuamos que hay al menos una palabra (en este caso la palabra "plowed") que se emplea metafóricamente en la oración, y que al menos una de las palabras restantes se emplea literalmente. Llamemos la palabra "plowed" el foco de la metáfora, y el resto de la oración en que esta palabra se presenta el marco $[\ldots]$. Entre otras cosas, sería bueno comprender cómo la presencia de un marco determinado puede conducir al empleo metafórico de la palabra complementaria, en tanto que la presencia de otro marco distinto para la misma palabra no conduce a la metáfora ${ }^{18}$.

Lo que Searle pone en tela de juicio en este argumento es la presuposición de que una palabra o serie de palabras comprendida literalmente pueda generar la interpretación metafórica de otra. Observa que en determinadas circunstancias resulta igual decir "Sally is a block of ice" que "Miss Jones is a block of ice" o "That girl over there in the corner is a block of ice", porque las pala-

${ }^{16}$ BLACK, op. cit., p. 37.

17 Ricoeur, op. cit., sobre todo el octavo ensayo.

${ }^{18}$ BLACK, op. cit., pp. 27-28. 
bras no son bases suficientes para la determinación del sentido metafórico. Señala también que no puede haber interacción entre marco literal y sentido metafórico en ejemplos tales como la frase de Russell, "Quadrilaterality drinks procrastination', donde todos los términos se emplean con sentido metafórico. Claro está que proposiciones como éstas se interpretan con respecto a un contexto no verbal "real" que pertenece a la situación comunicativa en la que se enuncian, pero ésta es precisamente la tesis que Searle quiere defender.

Cabe dudar, sin embargo, de que los enfoques de Searle y Black fueran realmente tan contrarios como la crítica (necesariamente esquemática) de Searle nos hace suponer a primera vista. En Black se encuentra el siguiente pasaje que por su riqueza conceptual cito in extenso:

Hasta ahora, he tratado la "metáfora" como predicado que se puede aplicar con propiedad a ciertas expresiones, sin prestar atención a cualquiera de las ocasiones en las que dichas expresiones se emplean, ni a los pensamientos, actos, sentimientos e intenciones de los que hablan en tales ocasiones. Y este procedimiento es seguramente adecuado para algunas expresiones. Reconocemos que decirle a un hombre "pozo negro" es emplear una metáfora, sin necesidad de saber quién emplea la expresión, ni en qué ocasiones, ni con qué intención. Las reglas de nuestra lengua determinan que algunas expresiones deben contar como metáforas; y el hablante es tan incapaz de cambiar eso como de decretar que "vaca" signifique lo mismo que "oveja". Pero debemos reconocer también que las reglas lingüísticas establecidas dejan un margen amplio a la variación, a las iniciativas, y a la creatividad del individuo. Hay un número indefinidamente grande de contextos (incluyendo casi todos los casos interesantes) en los que el significado de una expresión metafórica se tiene que reconstruir de las intenciones del hablante (entre otros indicios), ya que las reglas amplias del uso estándar son demasiado generales para proporcionar la información requerida. Cuando Churchill se refirió a Mussolini como "aquel utensilio", el tono de voz, la situación verbal, las circunstancias históricas, ayudaron a determinar cuál metáfora se empleaba. (Aun aquí, sin embargo, es difícil concebir cómo la frase "este utensilio" pudiera aplicarse a un hombre sin que fuera insulto. En este caso, como en otros, las reglas generales del uso operan para restringir la libertad del hablante para significar lo que le dé la gana.) Éste es un ejemplo, aunque todavía sencillo, de cómo para reconocer e interpretar una metáfora puede ser necesario prestar atención a las circunstancias específicas de su enunciación ${ }^{19}$.

${ }^{19}$ Ibid., p. 29. 
El párrafo contiene, sin duda, ciertos detalles objetables: "utensilio" puede no tener un valor despectivo como metáfora (se puede imaginar, por ejemplo, que una persona sea "utensilio" o instrumento de Dios o de la justicia), a diferencia del caso de las acepciones de "vaca" y "oveja" que el hablante no puede modificar o intercambiar a su antojo ${ }^{20}$. Pero lo que importa destacar en el comentario de Black es su caracterización sucinta de la naturaleza variable de la metáfora, que fluctúa entre los polos de las intenciones más personales del hablante y las convenciones más generales del lenguaje. Es precisamente este espacio de fluctuación posible el aspecto de mayor interés y provecho, en mi opinión, no sólo para la teoría general de la metáfora, sino también para su aplicación al análisis textual, ya que concebir los dos polos de esta variación como nociones absolutas implica de hecho desconocer la naturaleza misma de la metáfora. Por una parte, las metáforas enteramente personales serían incomunicables, y por otra, las completamente convencionales no dejan ningún lugar a la intención metafórica. Las metáforas completamente convencionales serían, a nuestra manera de ver, las que habrían sido completamente lexicalizadas como nuevas acepciones de las palabras por medio de las cuales se expresan.

Debido a lo anterior, la supuesta incidencia de la metáfora en la estructuración léxica de una lengua, tema que debería ser, según la concepción general, de gran interés para el lingüista, no es más que una tangente inútil para la discusión de los rasgos definitorios de la metáfora. Dedicarse a la arqueología de la metáfora en el campo lexicológico es instalarse sobre un terreno movedizo en el que todo límite entre lo metafórico y lo literal comienza rápidamente a esfumarse. El problema esencial está en que el definir una palabra como, por ejemplo, rascacielos, como metáfora (hiperbólica) no nos aclara en nada su funcionamiento ni su razón de ser en la comunicación. Este tipo de enfoque léxico debe reconocerse impotente, además, para captar la distinción de grado que intuitivamente se percibe, por ejemplo, entre las dos metáforas contenidas en la frase "the skyscrapers in the Big Apple". En suma, no interesa que las formas lingüísticas puedan o no comunicar sentidos metafóricos; lo que importa preguntar es si el

${ }^{20}$ Están en juego aquí distintos niveles de sistematicidad lingüística, a los que se refiere WiDDOwson con los términos de "use" y "usage", cada uno con sus reglas y procedimientos. Para estas distinciones, véase su trabajo "Rule and Procedures in Discourse Analysis", en T. E. Myers, ed., The Development of Conversation and Discourse, Edimburgh University Press, Edimburgh, 1979. 
hablante quiere o no emplear estas formas metafóricamente. La investigación sistemática de esta cuestión corresponde a una teoría de la pragmática del comportamiento verbal. Si este imperativo no ha sido debidamente reconocido, ha sido en parte por la falta de teoría explícita hasta fecha reciente.

La naturaleza variable de la metáfora abre perspectivas sociolingüísticas en el sentido más amplio del término, ya que el peso más o menos convencional de una expresión verbal remite de alguna manera al papel sociocultural del lenguaje y a la pertenencia del individuo a una comunidad lingüística. Podemos plantear, entonces, la posibilidad de situar la teoría searliana del funcionamiento de la metáfora en el marco de una teoría de la variación sociolingüística, cuyo interés para el análisis de la obra literaria destaca Roger Fowler:

es un hecho que las reglas de los "textos literarios" de las que se ocupa la poética descriptiva son muy diversas estilísticamente - sin embargo, no varían en forma aleatoria, ya que las repeticiones de hechos de estilo son muy visibles. Esta pluralidad estilística [...] es un postulado de la teoría global del discurso, y constituye también el punto de partida para estudios descriptivos. Una de las tareas primordiales de la sociolingüística es la descripción, la interpretación y la explicación de variedades lingüísticas, y aquel conjunto de actividades analíticas se vuelve aplicable e importante para la teoría de la literatura que presentamos aquí ${ }^{21}$.

Para comprender la pertinencia sociolingüística del lenguaje literario, hay que enfocarlo no como una variedad en sí, sino como punto de confluencia de diversas variables:

Un texto escrito, o un discurso oral, es (entre otras maneras pertinentes de enfocarlo) la mediación de un conjunto de ideas cuyas formas de expresión se derivan de una, o más normalmente, de más de una, variedad. "La literatura" no constituye una variedad en sí; cualquiera de los textos que se consideran literarios puede analizarse como construcción hecha a base de una o más variedades, de la misma manera, exactamente, que otros textos. Algunas de las variedades empleadas en la constitución de un texto "literario" específico podrían mostrar la tendencia a incidir en otros textos "literarios" (en algunos pero no todos), pero no se limitan a textos "literarios" (la rima y la aliteración se encuentran en anuncios comerciales); y los textos "literarios" también aprovechan patrones que tienden a presentarse en textos "no literarios" (tales como una

21 Fowler, op. cit., p. 192. 
conversación o un noticiero). Este traslapo estilístico, y la ausencia de todo criterio necesario y suficiente para el texto "literario", son hechos bien conocidos aunque con frecuencia se olvidan (ibid., pp. 20-21).

Este modo de acercarse al texto literario no implica que su composición estructural y estilística se tenga que medir en forma mecánica, ya que, como señala Fowler, cada variable textual puede realizar distintas potencialidades semánticas:

El valor de la teoría de las variedades lingüísticas para la poética descriptiva aumenta si a la noción de variedad sumamos la de función [...]. Si esta hipótesis se hace extensiva a la sociolingüística, es posible proponer que la selección consistente de variables sociolingüísticas constituye una variedad, realiza un conjunto congruente de opciones semánticas. Propongo que las variedades lingüísticas en el sentido sociolingüístico del término - registro, dialectos, códigos, lenguas distintas en diglosia- codifican distintos potenciales semánticos... (ibid., pp. 194-195).

Las variedades lingüísticas descritas de esta manera operan, de acuerdo con un enfoque funcionalista, como una serie de "códigos": "Un texto se concibe como la realización material de un discurso que involucra un número determinado de códigos 'seleccionados' de un repertorio pertinente a la función de la comunicación efectuada entre emisor y receptor(es)' (id.). El concepto de "código" ha conocido aplicaciones muy variadas, desde los códigos sociosemánticos que postula Basil Bernstein para explicar el comportamiento verbal de diferentes clases sociales en Inglaterra ${ }^{22}$, hasta los códigos semióticos y la dimensión filosófico-estética del proceso de la codificación a la que se refiere Paul Ricoeur:

En primer lugar, el discurso es el sitio donde se efectúa un trabajo de composición, o de "disposición" -para retomar el término de la retórica antigua - que hace de un poema o de una novela una totalidad irreductible a una simple suma de oraciones. Luego esta "disposición" obedece a reglas formales, a una codificación que

22 Basil Bernstein intentó, en el transcurso de los años sesenta, explicar el diferente comportamiento verbal de las clases sociales en Inglaterra por medio de su distinta orientación y potencialidad simbólicas, utilizando las nociones de "código elaborado" y "código restringido". Los fundamentos teóricos de su enfoque fueron expuestos en el primer tomo de su obra, Class, Codes and Control, Routledge \& Kegan Paul, London, 1971. 
ya no es de lengua sino de discurso, y que hace de éste lo que acabamos de llamar un poema o una novela. Este código es el de los "géneros" literarios, es decir, de los géneros que rigen la práctica del texto. Por último, esta producción codificada da como resultado una obra particular: tal poema, tal novela ${ }^{23}$.

Esta cita de Ricoeur resulta particularmente interesante para nosotros, porque trata uno de los temas centrales de Fowler y de otros especialistas de la lingüística del texto: el proceso de generar un texto. Es notable que en éste, uno de los pasajes de la obra de Ricoeur más directamente comparables con Fowler, el filósofo haya recurrido a la noción de "código", aun cuando la identifica someramente con la de "género"; cabe notar de todos modos que "género" aquí debe entenderse como un concepto generativo (ya que rige la práctica del texto), no como una simple categoría de la taxonomía estética de las obras literarias.

Considerando resumidamente los puntos de vista expuestos hasta aquí, dos ideas relacionadas con la metáfora parecen delinearse con especial claridad:

a) que la metáfora, como sentido indirecto, tiene su propia manera de funcionar, independiente en muchos aspectos del sentido literal, y que el tratar de definir o describir la metáfora en términos del sentido literal puede verse como un reduccionismo demasiado simplista;

b) que la discusión del funcionamiento de la metáfora nos lleva natural y legítimamente hacia una conceptualización dinámica del texto como producción verbal en un proceso de comunicación entre un emisor y un receptor, no como simple producto u objeto en cuya geometría estática el valor de la metáfora se reduce a la posición que ocupa.

Estas ideas no deben interpretarse como una manera de restar fuerza a la consideración de la parte que tiene la metáfora en la estructura de la obra literaria o del mundo referencial que propone; simplemente nos parece que estructura y mundo se comprenden mejor enfocando el proceso mismo de su construcción. Dentro de esta perspectiva, según parece, es como hay que interpretar la noción de mundo tal como la presenta Ricoeur: "la estructura de la obra es en efecto su sentido, el mundo de la obra su denotación [...] Interpretar una obra es desplegar (déployer) el mundo al que ella se refiere en virtud de su «disposición», de su "género» y de su «estilo»"24. Esta aseveración de Ricoeur parece

23 RiCOEUR, op. cit., p. 277 (el subrayado es mío).

${ }^{24}$ En las líneas que siguen a esta cita, Ricoeur pasa a tratar el papel de 
proponer una concepción de mundo que no se limita a la evidencia superficial del texto, sino que se va elaborando como proyección lógico-fenomenológica a cada paso de la generación textual.

la metáfora en la construcción del mundo referencial de la obra literaria. El asunto es problemático, según Ricoeur, ya que la obra literaria plantearía el caso insólito de un mundo sin referencia literal; "La «literatura" sería aquel tipo de discurso que ya no tiene denotación, sino solamente connotaciones" (ibid., p. 278). De ahí se postula que el mundo literario se construye por medio de una referencia de segundo nivel ("de second rang", o "second level" según la traducción inglesa, titulada The Rule of Metaphor, Toronto University Press, Toronto, 1977, p. 221), que sería precisamente una referencia metafórica. Por medio de tal enfoque Ricoeur establece un pretendido paralelismo entre lo que él llama metáfora de la referencia y metáfora del sentido: "Así como el enunciado metafórico es el que hace valer su sentido como metafórico sobre las ruinas del sentido literal, también es el que adquiere su referencia sobre las ruinas de lo que se puede llamar, por simetría, su referencia literal' (ibid., p. 279).

Pese a su innegable atractivo estético, el punto de vista de Ricoeur se fundamente en ciertas presuposiciones cuestionables que lo llevan, desgraciadamente, a un extremismo innecesario. La identificación de la "literatura" con la obra de ficción y con un tipo particular de discurso resulta sumamente difícil de sostener en términos empíricos. Pero esto nos llevaría a una discusión demasiado extensa como para incluirla aquí. Aceptando, pues, limitar nuestras observaciones a la ficción literaria, señalaremos que no existe una sola manera de definir ficción sino varias, todas cargadas de ideología: véanse, para esta cuestión, T. A. van Dijk, ed., Pragmatics of Language and Literature, en especial el ensayo de S. J. SCHMidT, "Towards a Pragmatic Interpretation of 'Fictionality' ', Poetics, 11 (1982); del mismo autor, "Fictionality in Literary and Non-Literary Discourse", Poetics, 9 (1980), 525-546; también J. F. IHwE y H. Rieser, "Normative and Descriptive Theories of Fiction. Some Contemporary Issues", Poetics, 8 (1979), 63-84; el número especial de Poetics titulado Semantics of Fiction; y por último, el tercer capítulo de SEARLe, op. cit., titulado "The Logical Status of Fictiomal Discourse".

Hay buenos argumentos a favor de considerar la ficcionalidad, no como cuestión de referencia, sino de pragmática; la ficcionalidad no reside en las características objetivas de la obra, sino en el tipo de contrato o de acuerdo que se establece entre autor y lector sobre la manera en la que éste va a leer la obra. No hay necesidad, entonces, de negar a la obra bases literales para que sea ficción, ni de suponer que el París de Balzac, por ejemplo, o el México de Carlos Fuentes, se hubieran podido nombrar de cualquier otra manera dado que son lugares imaginados. Y por más que se insista en la calidad imaginaria de Don Quijote, es innegable que sus rasgos físicos y espirituales, y el mundo en el que se mueve, le confieren un peso histórico. A diferencia de Ricoeur, quiero proponer que existe una relación constructiva entre referencia literal y creación literaria, más bien que una suspensión de la referencia literal para que surja la metafórica-novelesca. En suma, parece imposible la construcción de cualquier mundo, sea literario o no, sin denotación: la obra de ficción no es tal por su tipo de referencia o por su contenido metafórico, sino por su acto de enunciación en sí mismo. 
Tal concepción es muy amplia, pero no incompatible con los mundos, sub-mundos y series de mundos lógicos propuestos por algunos lingüistas del texto, para explicar la coherencia del texto y el paso desde su estructura subyacente hacia su forma lineal y superficial ${ }^{25}$.

¿Cómo se debe enfocar, entonces, ya más en concreto, la relación entre mundo y metáfora en la obra literaria? ¿Podemos aceptar la idea tradicional que Samuel Levin retoma en tiempos recientes, según la cual la obra literaria, y en particular el poe$\mathrm{ma}$, posee su propio mundo creado por el lenguaje? Para Levin, parece que la norma esencial de la construcción del mundo poético radica en la función estética de la creatividad individual y original: lo bello se centra en lo nuevo ${ }^{26}$. Según Levin, el mundo poético "no se crea por medio de alguna modificación sencilla y sin interés del estado real de las cosas, sino por medio de una ruptura radical y fundamental con ese estado"'27, y la manera en que el lector tiene acceso a este mundo es mediante la interpretación literal del lenguaje figurado:

se ha caracterizado a los poetas como "videntes", a los poemas como "mundos". Sin alguna concepción de la metáfora parecida a la que se presenta en este trabajo, tales características - si no es que son meras fórmulas retóricas- no son ellas mismas más que metáforas. En cambio, si concebimos las imágenes de un poema en función de lo que el lenguaje representa literalmente, entonces es congruente considerar al poeta como vidente, como vate, como profeta, inspirado, hasta loco de alguna manera - todas funciones o condiciones que se le han atribuido tradicionalmente. Por otra parte, el postulado de que el poeta es creador y el poema un mundo también encuentra apoyo en el enfoque sobre la metáfora que adoptamos aquí. Si se toma literalmente el lenguaje del poema, entonces el mundo representado es verdaderamente una creación (ibid., p. 133).

Dejando de lado el problema del alcance de esta caracterización del lenguaje metafórico - si se aplica a la poesía lírica exclusivamente, a la poesía en general, o si se hace extensiva, aunque

${ }^{25}$ Para tal enfoque, véanse sobre todo van Dijk, y la obra de J. S. PeTöFI en general.

${ }^{26}$ Ricoevr sigue una línea de argumentación semejante e igualmente equivocada a mi manera de ver, en algunas de sus reflexiones sobre la naturaleza de la obra literaria, cf. n. 3.

27. Levin, "Standard Approaches to Metaphor...", pp. 133-134. 
sea en forma parcial, a toda obra literaria-, se pueden señalar en ella varias deficiencias teóricas y prácticas. En primer lugar, la ruptura radical con el mundo "normal" que plantea Levin podría ser un concepto adecuado a la interpretación de un poema concreto, pero no base de una estética coherente. La originalidad del poeta no puede entenderse en un sentido absoluto, sino sólo en relación con una tradición, a cierta conformación ideológica de lo "normal", inclusive en las estéticas de base individualista. En segundo lugar, la identificación que Levin parece hacer entre la ruptura con el mundo normal y lá creación de un mundo mágico, fantasioso, resulta aún más discutible. Implica reducir la poesía a funciones escapistas, casi diríamos al nivel de un cuento de hadas, si no fuera que el cuento de hadas también puede tener valor literario, precisamente en caso de que constituya una reflexión seria sobre el mundo "normal", Nuestro concepto intuitivo de la originalidad se ajusta mejor a tal actitud reflexiva que a escapismos y fantasías.

Estas objeciones no son, sin embargo, tan centrales a nuestro tema como la que le podemos hacer a la propuesta de Levin de reinterpretar la metáfora en sentido literal. Fuera del marco de una teoría de la sustitución, criticada por Black como vimos arriba, y tan insatisfactoria para la obra literaria como lo es para el lenguaje en general, es difícil comprender cómo se implementaría la propuesta leviniana en términos prácticos. Esta dificultad se hace patente en su comentario del siguiente poema de Emily Dickinson:

The mountain sat upon the plain

In his eternal chair, His observation manifold, His inquest everywhere.

The seasons prayed around his knees,

Like children round a sire:

Grandfather of the days is he,

Of dawn the ancestor ${ }^{28}$.

${ }^{28}$ Sería imposible ofrecer aquí una traducción adecuada del poema, y de sus aspectos comentados por Levin, al español. Pero para facilitar en lo posible la comprensión del texto, ofrezco la siguiente versión que, por literal y directa, resulta mediocre y parcial (huelga decir que yo, no Emily Dickinson, soy el responsable de la pobreza poética del resultado): "La montaña estaba sentada en el llano/ en su asiento eterno,/ su observación era múltiple,/ e inquiría en todas partes./ Las estaciones oraban alrededor de sus rodillas,/ como niños alrededor de un señor:/ él es abuelo de los días,/ antecesor del alba". 
Según Levin, una interpretación tradicional describiría el poema de una manera "extraordinaria" o pintoresca de expresar una experiencia ordinaria, la de percibir una montaña como alta y vieja. Levin, en cambio, situaría el carácter "extraordinario" del poema en su concepción misma: concebiría un mundo en el que las montañas se sientan, ven, etc. Sin detenernos en el problema de determinar lo que esta visión extraordinaria de la montaña tiene de original o de valor literario, podemos concebir otras interpretaciones (más ricas) del poema en las que la montaña no constituye literalmente el tema, sino que es símbolo de otra cosa, de una figura patriarcal, centro de autoridad, de un "dios", por ejemplo, con lo cual la descripción natural que leemos en la superficie del poema cobra la dimensión de una reflexión filosófico-religiosa sobre la existencia. Lo que importa señalar aquí no es la mayor o menor legitimidad de tal interpretación, sino la imposibilidad de llegar a ella con el enfoque limitado de Levin. Son, precisamente, las metáforas religiosas de tipo convencional en el poema las que nos llevan naturalmente a atribuir un valor simbólico a la imagen central. Este valor siempre tendrá, claro está, cierto margen de ambigüedad porque depende de las inferencias del lector sobre las intenciones comunicativas del poeta, pero ¿cómo llegar a él razonablemente sin dejar a la metáfora su función simbólica (y para la obra literaria, también estructural) de metáfora?

Aunque Levin no comenta las metáforas comunicadas por las palabras "eternal", "chair", " "prayed", "inquest", "sire" etc., debido a su falta de originalidad, es evidente que tienen una función estructural bien definida como una serie de elementos que contribuye a la coherencia referencial del texto. A raíz de esta observación podemos luego preguntar si las metáforas mencionadas dirigen la atención del lector hacia la imagen central de la montaña, o si es la imagen central la que nos hace interpretar estas metáforas como serie. ¿O será que los dos movimientos interpretativos operan a la vez? Quizá la especificidad del texto literario tenga que ver con su textura, con el hecho de que su coherencia se establece un poco menos automáticamente que en textos más corrientes o sencillos.

Siguiendo el ejemplo de Levin, podemos ocuparnos brevemente del carácter lírico del poema. Si bien, como acabamos de ver, no se excluye la importancia de metáforas convencionales en el género lírico, podríamos atribuir por inferencia un valor personal al símbolo de la montaña, que se sitúa luego en un marco de referencia universal, la naturaleza en general. El potencial semántico que así se establece nos permite ver el poema a la vez como refle- 
xión sobre la existencia personal y sobre la condición humana en general.

Pasando ahora del poema concreto al nivel del "código" o del “'género'” (según la formulación de Ricoeur), podemos preguntarnos si la doble vertiente (personal-general) del poema de Emily Dickinson constituye un rasgo genérico. El simbolismo personal del poema lírico nos parece ser la base de la originalidad conceptual que Levin busca en él, pero este simbolismo no permite por sí mismo delimitar las fronteras del mundo referencial del poema. La poesía lírica ha tenido siempre su parte convencional, que tal vez explique en gran medida la evolución misma del género (ya que sabemos que temática y estructuralmente la poesía lírica ha cambiado en el transcurso de los siglos). Dicho con otras palabras, la propiedad simbólica del individuo no tiene un contenido constante, sino que se define de acuerdo a contextos históricosociales.

Para enfocar más explícitamente la variabilidad de las funciones metafóricas en la poesía lírica, pasaremos a comentar dos textos del poeta modernista mexicano Enrique González Martínez. Ambos son de los más conocidos y reconocidos por su calidad artística. Provienen del mismo libro, Los senderos ocultos, de 1911. Huelga mencionar la importancia del primero, "Tuércele el cuello al cisne", como hito en la historia del movimiento modernista, en virtud de su crítica a una belleza meramente superficial y decorativa, y de su exhortación a una poesía más cerebral y profunda, con la que se inicia la llamada segunda etapa del modernismo.

Las consabidas imágenes centrales del famoso soneto, el cisne y el búho, funcionan como temas de sus dos partes, de los cuartetos y de los tercetos respectivamente. Como imágenes temáticas, parecen funcionar a la vez como metáforas y como símbolos, su valor metafórico es explícito y enteramente convencional; como símbolos, en cambio, podrían tener (por inferencia) valores más personales y menos claramente definibles. El valor metafórico del cisne se establece en forma directa y evidente por su intertextualidad (sobre todo en relación con la producción rubendariana desde $A z u l$ ). La convención que asigna los atributos de inteligencia y sabiduría al búho es de raíz mucho más antigua y universal; tiene más que ver con lo que Jung llamaría el "inconsciente colectivo" que con un pensamiento de base racional. Como las metáforas del hielo y del gorila citadas por Searle, el búho es sabio (o el zorro es listo) no por lógica, sino por una tradición simbólica cultural. González Martínez subraya la diferencia de alcance de las dos imágenes, asociando el búho con el mundo clásico, y de ahí con 
una tradición de búsqueda de excelencia artística que de alguna manera engloba el modernismo. Pese a la amplitud referencial de estas metáforas, no debemos olvidar que deben su carácter claro y específico en este poema al contexto histórico-cultural específico de su enunciación, es decir, que se vinculan con una intencionalidad clara por parte del autor.

Las otras metáforas del primer cuarteto son de importancia puramente local:

Tuércele el cuello al cisne de engañoso plumaje que da su nota blanca al azul de la fuente;

él pasea su gracia no más, pero no siente

el alma de las cosas ni la voz del paisaje ${ }^{29}$.

Lo que acaso nos llama la atención más directamente en el estilo de esta estrofa es la combinación de metáfora y metonimia. La tradición modernista enunciada en la metáfora del cisne se hace aquí espacio, paisaje, vista y oído; y las metonimias "el azul de la fuente" y "[el cisne] pasea su gracia" son también metáforas debido, precisamente, a su referencia a la tradición modernista. De nuevo es el sentido enunciativo, no el sentido léxico de las palabras, el que permite establecer esta relación.

Hay tres imágenes más que debemos considerar brevemente en esta estrofa: "el alma de las cosas" y "la voz del paisaje" son ejemplos poco llamativos de un mecanismo metafórico universal, la personificación. Tienen, sin embargo, cierto interés por sugerir una dimensión espiritual oculta en un ambiente que se describe en términos primordialmente físicos. La imagen de la "nota blanca" es, en potencia por lo menos, más sutil y ambigua que las anteriores. La nota se puede ver, de hecho, como amalgama de las dimensiones sonora y visual de la descripción, a las que aludimos arriba. La acepción de nota como "marca escrita" constituye su valor etimológicamente primitivo (en el latín, por ejemplo), del que derivan las acepciones "marca escrita en una partitura" y "sonido de una frecuencia determinada, tocado por algún instrumento musical" desde la época en la que se inicia la transcripción musical de tipo tonal.

De lo anterior se desprende que se le puede dar a la imagen una lectura polisémica. La intertextualidad modernista del poema respalda la interpretación metonímica de la nota como "can-

${ }^{29}$ Las citas de los poemas de González Martínez se toman de la edición de sus obras completas preparada por El Colegio Nacional (México, 1971). 
to" 30 , mientras que la adjunción del adjetivo "blanco" abre la posibilidad de que la acepción de nota 'marca escrita' se extiende a la de 'pincelada de un cuadro' (que contrasta cromáticamente con el "azul de la fuente"). La fusión sinestésica de las artes que así se establece por referencia implícita encuentra amplio apoyo en la intertextualidad modernista. La acepción 'marca escrita en una partitura' también subsiste como una virtualidad textual, respaldada por su valor de representación icónica del cisne (recuérdese la explotación de valores semejantes en la sección "Los cisnes" de Cantos de vida y esperanza de Rubén Darío). Aunque esta compleja red de posibilidades simbólicas simultáneas parece depender, a primera vista, de su contexto verbal, sólo cobra coherencia desde el momento en que el lector intenta inferir las intenciones del autor. La sinestésica pluralidad de imágenes sería, por ejemplo, puro efecto gratuito si no viéramos en ella una alusión consciente a la praxis modernista.

La segunda estrofa, en la que González Martínez resume su ars poetica, no aporta novedades en el terreno de la metáfora:

Huye de toda forma y de todo lenguaje que no vayan acordes con el ritmo latente de la vida profunda... y adora intensamente la vida, y que la vida comprenda tu homenaje.

Frente al cuadro tan pobre que aquí se ofrece, el lector puede atribuir rasgos de metáfora a "huir", "comprender", y a las imágenes musicales y espirituales de "acordes", "latente", "profunda" y "adora". Pero estos valores están tan cerca de las acepciones normales de los términos léxicos, cuyos sentidos literales constituyen en realidad, que no parece existir un espacio semántico suficientemente amplio para que se perciban como metáforas. De nuevo, se debe recalcar la importancia del carácter intencional del lenguaje simbólico: donde el lector no puede inferir cierta voluntad de expresión figurativa de parte del autor (aunque ésta sea, en el caso extremo, inconsciente), deja de existir, entre otras figuras, la metáfora.

No obstante lo anterior, podemos señalar cierta motivación figurativa, siquiera en potencia, de los términos " acordes" y " profunda', el primero porque prolonga la serie de alusiones musica-

30 Agrupamos las figuras retóricas de sinécdoque y de metonimia bajo la designación única de metonimia, de acuerdo con el proceder normal de la semántica lingüística moderna. 
les que presenta la primera estrofa, el segundo por su especial significación intertextual en la obra de González Martínez. Este carácter potencial del lenguaje simbólico en el poema constituye, naturalmente, un aspecto de la apertura de la obra literaria hacia sus distintas lecturas posibles.

En la segunda mitad del soneto, el lenguaje figurado parece cambiar junto con el cambio temático:

Mira el sapiente búho cómo tiende las alas desde el Olimpo, deja el regazo de Palas y posa en aquel árbol el vuelo taciturno...

Él no tiene la gracia del cisne, mas su inquieta pupila, que se clava en la sombra, interpreta el misterioso libro del silencio nocturno.

El monte Olimpo y la diosa Palas son imágenes de mayor alcance textual que las anteriormente estudiadas: ayudan a explicitar el sentido global de la imagen del búho en vez de individualizar los atributos del mismo. Su carga histórico-cultural explícita, como figuras de los valores espirituales, las artes y la sabiduría, crea un espacio simbólico cuya función central es la de dar mayor realce a la importancia representativa del ave nocturna. En este proceso percibimos de nuevo que la metáfora no opera aisladamente, sino complementada por metonimias y hasta deícticos. La mención de "aquel árbol" ayuda a concretar los vínculos del ámbito histórico con el presente del poeta: se sugiere que el búho recorre una trayectoria espacio-temporal que parte de un pasado y un país remotos para llegar a un presente cercano en que el poeta puede señalar con precisión la posición del árbol. Metonímicas, por su parte, son las imágenes del "vuelo taciturno" (si leemos "taciturno" como modificador de "vuelo" y no del búho mismo) y de la "inquieta pupila" (sustituto de "mirada"), mientras que es por designación metafórica que el búho es "sapiente" y que su mirada "se clava" en la sombra. Ambas metáforas no son en absoluto originales. Parece imponerse, en suma, la conclusión de que, si bien el poema no carece de matices personales ( $\mathrm{y}$ el poeta los enuncia sintiendo su importancia vital), su incidencia en la expresión metafórica del poema es mínima. Las metáforas ceden algo de su eficacia simbólica a las necesidad de constituir signos que denotan tradiciones artístico-literarias; su peso es enteramente convencional.

"Psalle et sile" se diferencia del poema anterior tanto por su métrica como por la naturaleza más íntima de su tema: nuestra 
mirada enfoca ahora la vida personal del poeta. Pero impera el mismo tono didáctico, tan característico en la poesía de González Martínez, esta vez como exhortación a controlar las emociones y mantener una actitud serena, incluso resignada, frente a la vida. Las cinco estrofas del poema están organizadas en forma tal que la segunda mitad del texto constituye una especie de reflejo al revés de la primera; los versos iniciales y finales son casi idénticos. De esta manera, la disposición formal del poema parece subrayar el paralelismo entre vida interior del individuo y vida exterior del mundo que se va elaborando a lo largo del poema, y que constituye el eje central de su estructuración simbólica. No comentaremos ésta en todos sus detalles, para poder concentrarnos mejor en el papel específico de la metáfora.

Un primer punto de contraste con el poema anterior es que las metáforas de "Psalle et sile" se juntan en cadenas que contribuyen directamente a la cohesión léxica del texto: "quema... el incienso de tu santa inquietud"'; "sube por la escala del sueño"; "la vida... gran lago cuajado... que lleva... las estelas de todas las sonrisas/ y los surcos de todos los dolores". Esto, por supuesto, se debe a razones más fundamentales: todas las metáforas parecen desempeñar una función más directa que en el poema anterior en la construcción del eje simbólico del poema, es decir, la serie de correspondencias entre una realidad externa y otra interior. En este proceso los símiles complementan las metáforas, y hay un movimiento de vaivén entre el lenguaje figurado explícito y el simbolismo implícito. Este movimiento permite un desencadenamiento general de potencialidades simbólicas en todo el lenguaje del poema, factor que influye sobre todo en nuestra interpretación de la tercera estrofa, como luego veremos.

La polaridad esencial del poema se manifiesta desde la primera imagen figurativa señalada explícitamente como tal, "la fuente escondida", fuente de las lágrimas del sufrimiento espiritual del poeta. Es en la segunda estrofa, sin embargo, donde se comienza a apreciar verdaderamente la arquitectura del poema: las metáforas se enriquecen mutuamente en un paralelismo entre tres movimientos de ascensión que pertenecen a tres distintas áreas vivenciales del ser humano: la espiritual, la onírica y la natural. El humo del incienso sube en el aire como el soñador sube por la escalera del sueño y el vapor sube del mar para formar nubes. Con tal paralelismo sería difícil que las imágenes del mar y del cielo -denotado por la perífrasis modernista del "azul inmenso" - no adquirieran para el lector nuevos valores simbólicos en vez de limitarse a referencias objetivas literales. 
El mismo enriquecimiento potencial se extiende luego a todo el cuadro objetivo de la tercera estrofa:

Y guarda la mirada que divisaste en tu sendero - una

a manera de ráfaga de luna

que filtraba el tamiz de la enramada-;

el perfume sutil de un misterioso

atardecer; la voz cuyo sonido

te murmuró mil cosas al oído;

el rojo luminoso

de una cumbre lejana;

la campana

que daba al viento su gemido vago...

"Mirada", "sendero", "ráfaga de luna", "tamiz de la enramada", etc., son todas metáforas en potencia: su valor intencional como tales sólo se puede inferir de la enunciación de otras metáforas, con lo cual vemos que, aun cuando no aceptemos la tesis de Black sobre la presunta interacción entre lenguaje metafórico y lenguaje literal, las interacciones metafóricas sí pueden tener un papel creativo en el texto poético. La imagen que expresa la correspondencia exterior-interior en forma más clara es quizá " el tamiz de la enramada" que recuerda, como representación figurada de los ojos del poeta, la belleza decorativa de la perífrasis shakespeariana de The Tempest: "the fringed curtains of thine eye'" 31 .

Si consideramos la "originalidad" de las metáforas, también notamos una progresión desde las convencionales al comienzo del poema hacia los matices más personales de la tercera estrofa. La "'escala del sueño" es, según Jung, un “motivo"' de los más antiguos en la imaginación humana ${ }^{32}$, y vale decir lo mismo de la imagen de la fuente. De otra naturaleza son, sin embargo, la "ráfaga de luna", por ejemplo, o la única metáfora explícita de la tercera estrofa, "el gemido vago" de la campana. Aunque aquí la técnica básica de la personificación no es, obviamente, un elemento novedoso, el sonido inusitado de lamento que emite la campana sirve para subrayar el tono íntimo de toda la descripción objetiva.

Las operaciones metafóricas vuelven a ser completamente ex-

31 W. Shakespeare, The Tempest, acto I, escena II, 1. 405.

32 C. Jung, Dreams, trad. R. F. C. Hull, Princeton University Press, Princeton, 1974 , p. 131. 
plícitas al final del poema, en las estrofas cuarta y quinta. Prosiguiendo con el inconfundible tono onírico de la primera estrofa, la cuarta se inicia a su vez con un símil líquido: "la vida debe ser como un gran lago" cuya superficie congelada lleva las marcas de toda la gama de las emociones humanas ("sonrisas y dolores'). La imagen de una superficie blanca en la que se inscriben marcas significantes permite al lector pasar naturalmente de la metáfora del lago a la de la página que se enuncia por implicación en la quinta estrofa: las emociones que siente el poeta quedan "impresas" en su ser, de donde podemos suponer que pasan al texto impreso del poema:

\author{
Cada emoción sentida, \\ en lo más hondo de tu ser impresa \\ debe quedar, porque la ley es ésa: \\ no turbar el silencio de la vida, \\ y sosegadamente \\ llorar, si hay que llorar, como la fuente \\ escondida...
}

Este breve comentario de los dos poemas ha sido, sin duda, una manera de recorrer un camino conocido. No ha llevado a importantes descubrimientos originales en la interpretación de los textos. Pretende simplemente explicitar lo que muchos o todos sabemos e inferimos sobre las metáforas de dos poemas célebres. En primer lugar, espero haber demostrado que las metáforas constituyen sólo un aspecto — quizá el más claramente enunciado y enunciable - de la articulación simbólica de un poema, pero que sería un error descuidar otros elementos de este complejo proceso: los metonímicos, icónicos, etc. Una teoría de la metáfora nunca podría ser, entonces, base suficiente para la exégesis de la obra literaria, ni del texto poético en particular, dado que la supuesta preeminencia de la metáfora en la poesía es, como ya vimos, más aparente que real.

Ya que la metáfora puede, por otro lado, guardar una relación íntima e indisoluble con el marco simbólico que propone el poema (sin que esta relación deba tomarse como una necesidad axiomática), será normalmente insuficiente, para la explicación del funcionamiento textual de la metáfora, una teoría que reduzca valores metafóricos a valores literales. Como ya vimos, Black critica tal postura haciendo una distinción entre el discurso científico y el que necesita metáforas. Para el caso de la poesía, la postura es aún menos sostenible: nada más ilógico, en efecto, que el querer reducir a una lógica unívoca y literal un discurso que 
se empeña en ser ambiguo, en dejar sin decir, como simple potencialidad significativa, una parte tan esencial de lo que el poema de todos modos comunica. Vimos sobre todo en "Psalle et sile"' cómo las metáforas (aun las más explícitas) pueden respaldar esta ambigüedad fundamental. Y el que el poeta no diga mucho de lo que su poema logra comunicar es, de hecho, una necesidad ineluctable, dado que, como señala Tomás Segovia ${ }^{33}$, su lenguaje simbólico remite por definición a un no-saber. Pero la metáfora, aunque parezca contradictorio, pertenece precisamente al acto de enunciación; es, si queremos, el algo que no dicen las palabras (el lenguaje literal) pero que pensamos que alguien (el emisor implícito) quiere decir. Desde el momento en que el símbolo reviste intencionalidad comunicativa (porque se ha vuelto algo que puede decirse), pasa a ser metáfora.

Aunque la metáfora como lenguaje simbólico no enuncia hechos verificables, sería un error relegarla a un lenguaje irreal (incluso en la obra de ficción), negándole su parte de reflexión seria sobre la realidad. Como sentido enunciado, la metáfora tiene importancia ideológica; como sentido figurado no es verificable, pero se aplica o se refiere a situaciones y objetos reales que sí lo son. $\mathrm{Su}$ función de vincular lo enunciado y lo no enunciable explica en parte la amplitud y variabilidad de su funcionamiento en el texto poético. Se ha constatado esta variabilidad de manera empírica en nuestro análisis de los dos poemas de González Martínez. En la primera parte de "Tuércele el cuello al cisne", las metáforas desempeñan una función esencialmente ornamental y local, y si tienen mayor alcance referencial en la segunda parte del poema, es porque el "mundo" o el marco referencial del búho debe ser más amplio que el del cisne. Las metáforas son explícitas y convencionales, como debe ser cuando cumplen la función de poner valores simbólicos al servicio de argumentos racionales.

En "Psalle et sile" el papel estructural de las metáforas es muy distinto: se articulan en series porque su interacción debe contribuir a la expresión de una visión cósmica de la existencia (si, como vimos, Searle invalida la idea de la interacción del sentido metafórico con su entorno literal, podemos, en cambio, admitir la importancia del principio de la interacción entre sentidos metafóricos en el texto literario). El poeta ve la existencia individual como reflejo y microcosmo de la existencia general, del orden del mundo; por eso, las emociones individuales deben ser también

${ }^{33}$ En su artículo "Owen, el símbolo y el mito", NRFH, 29 (1980), $556-573$ 
privadas, callándose frente al gran silencio del mundo. Y si la existencia es cosmos, lo general también es espejo de lo particular, el gran espacio de la naturaleza se hace escenario de las vivencias personales. Pero esto lo sugiere el poeta implícitamente antes de decirlo explícitamente, porque el lector debe descubrir esta verdad por sí mismo para convencerse de la validez de las exhortaciones del poeta. Para establecer esta reciprocidad entre lo implícito y lo explícito, la metáfora constituye un instrumento indispensable.

Lo anterior ya nos sugiere dos parámetros significativos para la descripción de la variabilidad metafórica en el texto literario, que se planteó arriba como posibilidad teórica. El sentido más o menos convencional de las metáforas, y su contribución más o menos importante a la coherencia textual (su organización en series y su relación con los temas principales del texto, o bien su funcionamiento individual) podrían ser criterios razonables para una clasificación intertextual del lenguaje metafórico, a los cuales se podría sumar quizá un parámetro que no se ha podido evaluar en este breve estudio: la realización gramatical de la metáfora (a nivel de palabra, frase, oración o conjunto oracional). Tales parámetros podrían luego organizarse tal vez en índices de variabilidad estilística que permitieran medir el grado de pertenencia de un texto determinado a un género o subgénero literarios.

Otro aspecto sociolingüísticamente importante de la metáfora es su función de implementar en el texto "códigos" sociosemánticos del tipo mencionado por Fowler. En este sentido, la metáfora tiene importancia como elemento textual generador de esquemas ideológicos. Claro está que estos esquemas constituyen conjuntos estructurados en los que cada "código" enunciado sólo resulta significativo por medio de su relación con el todo. La presencia de metáforas religiosas en un soneto de Góngora, por ejemplo, no hace de él poesía religiosa. No se me escapa la dificultad de llevar este tipo de consideraciones a una cuantificación confiable, pero como hipótesis parece enteramente razonable sostener que los textos literarios se insertan en el conjunto de textos generados en determinado ámbito de producción social gracias, en parte, al peso ideológico de su lenguaje figurado. La configuración ideológica del texto (literario o no) se define, en suma, como una cuestión intertextual. Cabe destacar, por último, que tal cuestión ni siquiera se podría enfocar sin una teoría que vinculara la metáfora con el acto enunciativo.

En conclusión, quiero apuntar que soy consciente de las necesarias limitaciones del enfoque que me propuse adoptar en estas páginas. Explorar el funcionamiento textual de la metáfora no im- 
plica, de ninguna manera, adentrarse en la problemática de su razón de ser, problemática cuyo debido tratamiento corresponde a la filosofía y a la semiótica. Un buen punto de partida para esta empresa se encuentra, a mi manera de ver, en la distinción esbozada por Tomás Segovia entre lenguaje mítico, literal y simbólico. La metáfora en sus diferentes aspectos ofrece - así lo prueban los estudios sobre el tema producidos en los últimos años- un fructífero campo de cooperación interdisciplinaria. Espero haber demostrado aquí siquiera que un tema común de lingüistas y críticos literarios no lleva necesariamente a un diálogo de sordos.

El Colegio de México

RODNEY WILLIAMSON

Universidad de Ottawa, Canadá 